\title{
Pengembangan media pembelajaran fisika berbasis multimedia swishmax 4 dengan pendekatan saintifik materi kalor SMA kelas $\mathrm{X}$
}

\author{
Debby Kusuma Wardhani, Winarto*, Lia Yuliati \\ Universitas Negeri Malang, Jl. Semarang No. 5 Malang, Jawa Timur, Indonesia \\ *Penulis korespondensi, Surel: winarto.fmipa@um.ac.id
}

Paper received: 01-07-2021; revised: 15-07-2021; accepted: 31-07-2021

\begin{abstract}
Abstrak
Kurikulum 2013 dengan pendekatan saintifik mendorong siswa aktif dalam pembelajaran. Pembelajaran aktif dicapai apabila proses belajar menyenangkan. Penggunaan media pembelajaran berbasis multimedia membuat pembelajaran menyenangkan karena multimedia dilengkapi unsur gambar, teks, animasi dan suara. Tujuan dari penelitian dan pengembangan ini adalah menghasilkan dan mengetahui tingkat kelayakan media pembelajaran fisika yang dikembangkan. Metode penelitian yang digunakan adalah metode penelitian dan pengembangan dari Sukmadinata yang menggunakan 3 langkah pengembangan. Hasil penelitian menunjukkan bahwa media pembelajaran fisika berbasis multimedia Swishmax 4 dengan pendekatan saintifik pada materi kalor layak digunakan untuk siswa SMA kelas X. Media pembelajaran ini layak dengan nilai ratarata kelayakan media sebesar 86,31 persen dan rata-rata kelayakan materi sebesar 82,71 persen.
\end{abstract}

Kata kunci: Media; multimedia; saintifik; kalor

\section{Pendahuluan}

Pendekatan saintifik kurikulim 2013 merupakan pendekatan yang wajib digunakan guru dalam proses pembelajaran. Pendekatan saintifik yang diwajibkan dalam pembelajaran pada kurikulum 2013 ini telah ditetapkan dalam Peraturan Mentri Pendidikan dan Kebudayaan Nomor 81 A tahun 2013 Lampiran IV. Diterapkannya pendekatan saintifik diharapkan siswa lebih aktif dalam pembelajaran. Siswa dapat dikatakan aktif dalam pembelajaran apabila secara fisik dan emosional juga aktif. Sehingga proses pembelajaran dapat berjalan dengan baik. Untuk memenuhi hal tersebut guru dituntut untuk berinovasi mencari tahu bagaimana cara membangkitkan emosonal siswa melalui modifikasi berbagai strategi pembelajaran sehingga proses belajar menjadi menyenangkan.

Penggunaan media pembelajaran berbasis multimedia membuat pembelajaran menjadi menyenangkan, karena multimedia dilengkapi dengan unsur-unsur gambar, suara, animasi dan teks. Pernyataan in diperkuat dari hasil penelitian yang dilakukan oleh Wahyuni (2011) menyatakan ada perbedaan skor ata-rata belajar antara siswa yang dilibatkan dalam pembelajaran dengan pemanfaatan multimedia dan tanpa multimedia.

Pembuatan media pembelajaran berbasis multimedia dapat dilakukan dengan bantuan software. Menurut Kamaludin (2013) Software Swishmax 4 adalah software yang mampu mengabungkan unsur-unsur multimedia dengan baik. SwishMax memiliki kemudahan yang dapat menghasilkan animasi 2D dengan kompleksitas unsur baik text, image, grafik, maupun suara, dapat pula disimpan dalam bentuk file video sehingga mudah dalam pemakainannya.

Salah satu mata pelajaran yang membutuhkan multimedia dalam pembelajarannya adalah fisika. Menurut Waldopo (2011) menurut hasil penelitiannya, guru mata pelajaran fisika membutuhkan multimedia pembelajaran dalam pengajaranya dengan persentase 
sebesar $60 \%$ dibanding mata pelajaran lain. Beberapa konsep dalam mata pelajaran fisika sulit untuk dibayangkan bila siswa hanya membaca buku dan melihat gambar. Oleh karena itu diperlukan sebuah media pembelajaran yang mampu memvisualisasikan konsep-konsep dalam fisika. Salah satu materi pada pmbelajaran fisika yang sulit dipelajari bila hanya dibayangkan adalah kalor. Materi kalor menjelaskan bagaimana pergerakan partikel atom suatu benda bila berinteraksi dengan lingkungan, hal inilah yang membuat pentingnya mempelajari kalor dengan bantuan multimedia.

Hasil studi pendahuluan yang telah dilakukan peneliti di SMA Negeri 6 Malang menyatakan bahwa mata pelajaran fisika pada bahasan kalor tergolong sulit dipelajari, dengan alasan sulit menghafal rumus dan kurang memahami penggunanaan rumus ketika diterapkan dalam soal. Sumber belajar yang digunakan adalah buku paket, LKS dan LDS. Hasil angket observasi lapangan menyatakan sebagian besar siswa menyukai animasi dan setuju bila animasi tersebut digunakan untuk menjelaskan konsep-konsep dalam materi kalor dengan alasan penggunaan animasi dapat menarik perhatian siswa, materi mudah untuk dipahami dan dapat membayangkan konsep kalor. Didukung dengan materi kalor adalah materi yang erat kaitannya dengan kehidupan sehari-hari akan semakin mudah dipahami jika materi tersebut disajikan dengan multimedia membahas fenomena yang dekat dengan kehidupan siswa.

Upaya untuk mengatasi permasalahan adalah dengan mengembangkan multimedia dengan pendekatan saintifik. Hal ini sesuai dengan penelitian yang telah dilakukan oleh Siti Nurlailiya (2014) penggunaan multimedia dengan pendekatan saintifik pada materi fluida statis layak digunakan sebagai media pembelajaran, dengan persentase kelayakan sebesar 95,5\% untuk isi dan 91\% untuk media. Multimedia pembelajaran dengan pendekatan saintifik adalah multimedia pembelajaran yang disusun berdasarkan langkah-langkah dalam pendekatan saintifik. Langkah-langkah yang disusun dalam media membatu siswa untuk mengkonstruksi pemahaman.

Dari uraian latar belakang yang telah ada maka perlu untuk mengembangkan media pembelajaran yang sesuai kurikulum 2013 yaitu dengan pendekatan saintifik. Media pembelajaran ini dibuat sebagai sarana dalam membantu guru menjelaskan materi dan siswa dalam mengkonstruksi pemahaman sehingga perlunya pengembangan media pembelajaran fisika berbasis multimedia swishmax 4 dengan pendekatan saintifik pada materi kalor SMA kelas X.

\section{Metode}

Metode penelitan yang digunakan adalah metode penelitian dan pengembangan yang dilakukan oleh Sukmadinata (2013). Pengembangan media pembelajaran fisika bebasis multimedia Swishmax 4 dengan pendekatan saintifik mengadopsi tiga langkah penelitian dan pengembangan yaitu (1) Studi Pendahuluan, (2) Pengembangan Produk, dan (3) Pengujian.

Teknik pengumpulan data yang digunakan dalam peneliti ini adalah angket. Angket yang digunakan dalam teknik pengumpulan data difungsikan untuk memperoleh data secara kuantitatif dan kualitatif. Data kuantitatif yang diperoleh dari data hasil validasi ahli yang menggunakan skala Likert, data kuantitatif dipergunakan untuk mengetahui tingkat kelayakan produk. Sedangkan data kualitatif diperoleh dari kritik dan saran validator ahli dan hasil jawaban dalam angket keterbacaan dengan pertanyaan terbuka yang telah diperoleh dari siswa dalam uji coba terbatas. 
Teknik analisis data yang digunakan dalam penelitian pengembangan modul ini adalah dengan teknik persentase dan teknik analisis model Miles and Huberman. Data yang diperoleh dari skor angket dengan skala likert diolah dengan menggunakan teknik persentase, sedangkan jawaban dari pertanyaan terbuka dan kritik/saran diolah dengan teknik analisis model Miles and Huberman. Teknik analisis model Miles and Huberman dilakukan dengan tiga tahap, yaitu reduksi data, penyajian data dan verifikasi. Pada langkah reduksi yang dilakukan adalah merangkum dan memilih data-data yang pokok dan membuang yang tidak perlu, kemudian langkah kedua yaitu penyajian data, dilakukan dengan menyajikan data hasil reduksi kedalam tabel dan dilanjutkan dengan verifikasi yaitu dengan penarikan kesimpulan. Hasil dari verifikasi digunakan peneliti untuk melakukan perbaikan dan menyempurnakan produk. Adapun rumus yang digunakan untuk pengolahan data kuantitatif dari angket validasi media dan materi adalah sebagai berikut.

$$
P=\frac{\sum x}{\sum x_{i}} \times 100 \%
$$

Keterangan :

$P=$ Persentase

$\sum x=$ Jumlah skor jawaban tiap responden dari tiap item

$\sum x_{i}=$ jumlah total skor jawaban jika seluruh responde menjawab sama

\section{Hasil dan Pembahasan}

Media pembelajaran fisika berbasis multimedia Swishmax 4 dengan pendekatan saintifik materi kalor kelas X memiliki beberapa bagian tampilan, yaitu

\subsection{Home Menu}

Home menu berfungsi sebagai halaman yang memuat tombol navigasi untuk mengakases media menuju halaman petunjuk, tokoh, materi dan biodata. Halaman tersebut dapat diakses dengan menekan tombol yang dipilih. Tampilan menu dilengkapi dengan tombol exit yang memungkinkan pengguna untuk keluar dari media pmbelajaran tersebut.

\subsection{Petunjuk}

Halaman petunjuk berisi penjelasan fungsi tombol-tombol yang digunakan dalam media pembelajaran dan petunjuk penggunaan animasi. Media pembelajaran ini menggunakan box menu, yaitu sebuah kumpulan menu yang dirangkum dalam satu tepat yang memudahkan pengguna untuk beralih menuju halaman lain.

\subsection{Tokoh}

Halaman tokoh ini menampilkan tokoh guru dan siswa yang digunakan dalam media pembelajaran. Tokoh ini berfungsi untuk membantu memberikan perintah ataupun informasi kepada pengguna. Setiap tokoh dalam media ini memiliki biodata masing-masing. 


\subsection{Materi}

Pada halaman materi ini berisi 4 sub materi kalor yang dapat diakses dengan menekan tombol sub materi yang dipilih. Dilengkapi dengan tombol soal serta penilaian psikomotor dan afektif. Tampilan halaman materi ini juga dilengkapi dengan tombol home untuk kembali ke tampilan home serta tombol keluar jika ingin mengakhiri media pembelajaran. Pada bagian pertama membahas tentang sub materi suhu dan pemuaian, bagian kedua membahas pengertian kalor dan besaranbesarannya, bagian ketiga yaitu tentang Azas Black dan perubahan wujud zat, dan bagian keempat tentang pepindahan kalor. Masing-masing bagian disusun berdasarkan langkah-langkah dalam pendekatan saintifik yaitu mengamati, menanya, mencoba, menalar dan mengkomunikasi. Tampilan materi ini juga menampilkan tombol yang akan membawa pengguna menuju soal pilihan ganda yang dapat digunakan untuk evaluasi pada materi kalor.

Media pembelajaran fisika yang dikembangkan telah diuji cobakan. Dari analisis rata-rata tiap aspek pada validasi ahli media dan ahli materi, kemudian dapat diketahui kelayakan dari media dan materi. Setelah dilakukan pengambilan data maka diketahui bahwa media pembelajaran fisika berbasis multimedia Swishmax 4 dengan pendekatan saintifik pada materi kalor layak digunakan untuk siswa SMA kelas X. Media pembelajaran ini layak dengan nilai rata-rata kelayakan media sebesar $86,31 \%$ dan rata-rata kelayakan materi sebesar $82,71 \%$.

\section{Simpulan}

\subsection{Kajian}

Berdasarkan hasil validasi ahli media dan materi menyatakan bahwa media pembelajaran fisika berbasis multimedia Swishmax 4 dengan pendekatan saintifik layak digunakan dan dapat membantu siswa dalam proses belajar. Penggunaan pendekatan saintifik dimaksudkan untuk membuat siswa aktif dalam pembelajaran baik secara fisik maupun emosional, serta membantu siswa mencari dan menemukan informasi, sehingga dapat mengkonstruk sendiri pengetahuannya. Seperti yang telah diungkapkan oleh Marjan,dkk (2014) "pendekatan saintifik menekankan pada keaktifan siswa untuk membangun konsep dalam pengetahuannya secara mandiri, membiasakan siswa dalam merumuskan, menghadapi, dan menyelesaikan permasalahan yang ditemukan".

Penerapan pendekatan saintifik dalam media pembelajaran dapat membuat siswa aktif karena pembelajaran dikelas menjadi menyenangkan. Pengertian pembelajaran yang menyenangkan tidak dapat dimengerti hanya dengan ketertarikan siswa dalam media pembelajaran, namun dengan inovasi tersebut siswa mampu mencari dan menemukan sendiri informasi kemudian mengkonstruknya menjadi pemahaman.

Media pembelajaran ini adalah media pembelajaran berbasis multimedia. Penggunaan multimedia Menurut Bornman dan Solms dalam Gungoren (2012) menyatakan multimedia adalah kombinasi dari beberapa media yang memiliki tipe berbeda yaitu suara, animasi, teks, grafik dan video untuk menampilkan informasi lewat komputer. Selain penggunaan video media pembelajaran ini juga menampilkan 
animasi. Animasi yang ditampilkan adalah animasi analisis terjadinya suatu peristiwa maupun animasi yang menjelaskan langkah-langkah dalam percobaan, juga dilengkapi dengan grafik dan teks.

Pembuatan media pembelajaran berbasis multimedia dengan pendekatan saintifik ini menggunakan software Swishmax 4. Menurut Kamaludin (2013) SwishMax memiliki kemudahan yang dapat menghasilkan animasi 2D dengan kompleksitas unsur baik teks, image, grafik, maupun suara. Penggunaan software ini dapat mempermudah pengembangan media pembelajaran karena pengguaannya tidak memerlukan bahasa pemrogaman yang rumit.

Media pembelajaran fisika berbasis multimedia Swishmax 4 dengan pendekatan saintifik pada materi kalor yang dikembangkan ini memiliki beberapa kelebihan, yaitu 1) media pembelajaran ini adalah media pembelajaran yang menyenangkan karena disusun dengan menggunakan pendekatan saintifik sehingga membuat siswa aktif dalam pembelajaran, 2) animasi yang ditampilkan adalah animasi yang membahas proses terjadinya suatu peristiwa dan animasi yang menjelaskan langkah-langkah dalam percobaan sehingga siswa mampu mengkonstruk pemahamannya, 3) Animasi, gambar dan video yang digunakan adalah peristiwa yang erat hubungannya dengan kehidupan sehari-hari sehingga materi lebih mudah dipahami. Selain kelebihan, media pembelajaran ini memiliki kekurangan, antara lain 1) media pembelajaran ini difokuskan untuk satu materi pokok bahasan yaitu kalor, 2) hanya terbatas pada model pembelajaran tertentu dan 3) penggunaan media pembelajaran ini masih membutuhkan praktikum yang dilakukan secara langsung.

\subsection{Saran}

\subsubsection{Saran Pemanfaatan}

Media Media pembelajaran ini memuat lembar kerja siswa yang didalamnya memandu siswa melakukan eksperimen sehingga pengguna disarankan menyiapkan terlebih dahulu peralatan yang akan digunakan untuk eksperimen.

Media pembelajaran ini memungkinkan untuk siswa menggunakannya secara langsung apabila fasilitas komputer disekolah mendukung.

\subsubsection{Pengembangan Produk Lebih Lanjut}

Pengembangan media pembelajaran ini hanya menggunakan model pembelajaran tertentu, perlu dikembangkan pada model lain sesuai dengan kurikulum yang ada. Pengembangan media pembelajaran ini hanya sampai pada uji coba terbatas. Agar media pembelajaran ini menjadi lebih baik maka perlu adanya uji coba empiric. Uji coba empirik dapat dilakukan dengan metode eksperimen. Metode eksperimen yang dilakukan dapat menggunakan dua kelas, yaitu satu kelas sebagai kelas kontrol dan satunya sebagai kelas eksperimen yang diberi pelakuan dengan diberikan media pembelajaran, sehingga diketahui kelayakan dari media pembelajaran ini. 


\section{Daftar Rujukan}

GÜNGÖREN, Ö. C. (2013). Authentic learning in multimedia. The Online Journal of Distance Education and eLearning, 1(3), 14-19.

Marjan, J., Arnyana, I. B. P., \& Setiawan, I. G. A. N. (2014). Pengaruh pembelajaran pendekatan saintifik terhadap hasil belajar biologi dan keterampilan proses sains siswa MA. Mu allimat NW Pancor Selong Kabupaten Lombok Timur Nusa Tenggara Barat.Jurnal Pendidikan dan Pembelajaran IPA Indonesia, 4(1).

Kamaludin, K. (2013). Mengolah informasi dalam media interaktif menggunakan aplikasi swishmax. Baca: jurnal dokumentasi dan informasi, 34(1), 85-104.

Pendidikan, P. M., \& Nomor, K. R. I. (81). A tahun 2013 tentang Implementasi Kurikulum. Jakarta: Kementrian Pendidikan dan Kebudayaan Republik Indonesia.

Sukmadinata Nana, S. (2010). Metode Penelitian Pendidikan. Bandung: Remaja Rosdakarya.

Wahyuni, E. (2012). Pengaruh pemanfaatan multimedia dalam pembelajaran fisika terhadap pemerolehan belajar. Jurnal Visi Ilmu Pendidikan, 7(1).

Waldopo, W. (2011). Analisis kebutuhan terhadap program multi media interaktif sebagai media pembelajaran. J. Pendidik. dan Kebud, 17(2), 244. 